there are frequent references to them in a general introduction to the volume by W. S. Pitcher. The reader is, in fact, occasionally tantalized by a remark such as "It is of interest to note that the validity of the basic assump. tions [in isotopic dating procedures] could still be the subject of a vigorous debate". True to the original derivation of the word 'symposium', the meeting at Liverpool provided a feast of ideas (not all of which we have been able to mention here) as varied as the courses at a banquet and differing as widely in flavour and in nutritional value. They make a significant addition to the literature of motamorphism. The volume is described as Geological Journal Special Issue No. 1; we are encouraged to look forward to future special issues of similar quality.

F. C. Phillits

\section{ULTRASONICS IN MEDICINE AND BIOLOGY}

\section{Uitrasonic Energy}

Biological Investigations and Medical Applications. Edited by Elizabeth Kelly. Pp. 387. (Urbana, Ill. : University of Illinois Press, 1965.) 12.50 dollars.

ULTRASONIC Energy brings together summaries of achievement and research in most aspects of ultrasonio technology as applied to medicine and the biological sciences, and is a good description of the subject as it stood three years ago. It is largely, if not entirely, the proceedings of the symposium on "Ultrasound in Medicine and Biology", held in the University of Illinois in June 1962. It is a very well produced book with excellently prepared diagrams, photographs and microphotographs, many in good colour.

In medical and biological research to-day, ultrasonics is providing useful assistance toward diagnosis by the delineation of structures as an alternative to X-rays for soft tissues or where radiation damage might be dangerous, for example, in the diagnosis of pregnancy. It is also being used therapeutically for producing discrete brain and nerve lesions, and in smaller doses for treatments in physical medicine. In biology it assists investigations of cell structure, helps to identify proteins and augments the destructive effects of X-rays on malignant tumours. It has the advantage that it can be focused and directed into the body with considerable precision.

Ultrasonic Energy will bring many aspects of the subject to the attention of workers whose main study is limited to a particular branch. Medical readers will find much of interest and ideas worth further study.

There are twenty-six sections or articles, each prepared by an expert research worker. Eight of these sections are on diagnostic techniques (for the eye, brain, heart and abdomen) by the pulse-echo technique; four are on surgical uses of high-intensity ultrasound, two on the effects of ultrasound on malignant cells, two on the neuromuscular system, one on the liver with emphasis on cellular effects, one on the effects on the ear and one is an abstract of work on physical medicine. There are five good articles on the action of ultrasound in biological tissues at different intensities and analysis of the effects of cavitation, of gas bubbles and streaming of cell protoplasm.

Practically the entire contents of the book can be found elsewhere by searching the technical and medical literature, but there is convenience in their concentration in a single volume. The expert reader should, however, be reminded that the book has scarcely been re-edited since the conference and, of the copious references, only four are dated after 1962. The article on physical medicine is given in a half-page abstract because the writer could not attend the conference; suroly his full manuscript might have been obtained in the succeeding three years, especially as the book, in its title, does not purport to be a record of the conference but a text-book of the art. It contains verbatim reports of the discussions which followed each paper, even about films which the reader cannot see. As is usual in discussions in a large symposium, many of the remarks and questions are wide of the mark.

It surprises me that, with so much apparently known of the value of ultrasound coupled with X-rays for the destruction of malignant cells, this application has no advocates in the clinical field.

The contributors are from Europe and Japan as well as from many parts of the United States and it is internationally a comprehensive book.

C. N. SмYтн

\section{FROM LIGHT TO SIGHT: THE METABOLIC BASIS}

\section{Biochemistry of the Retina}

Edited by Clive N. Graymore. (1st International Symposium, London, September 1964.) Pp. xiv +172 . (London: Academic Press, Inc. (London), Ltd.; New York: Academic Press, Inc., 1965.) $60 s$.

$\mathrm{V}$ ISION is a complex process involving a multitude of phenomena ranging from the relatively simple refraction of light to the interpretation of the nervous impulses in the brain. Biochemistry of the Retina is concerned with some of the intervening processes by which quantum energy is transformed into chemical and electrical signals, how this highly specialized tissue is maintained in a functional state and how diabetes, retinal degeneration and retinotoxic substances which each disturb metabolism and function mey give a better understanding of normal processes.

Twenty papers were presented at the first international symposium on this subject and, although the approach and emphasis were extremely varied, the conclusions reached are entirely complementary. Discussion followed each paper, thus allowing alternative interpretations to be suggested and correlations with other findings to be emphasized. By including these, the editor has welded the individual reports into a coherent and valuable book.

Three papers deserve special mention, and a fourth, on the limitations in the use of tetrazolium salts for the histochemical localization of dehydrogenases, is important in view of the widespread use of this method in studying the retina. W. K. Noell examines the relationship between metabolism, light-evoked potentials (electroretinogram) and morphology of the retina, comparing normal animals, those with hereditary retinal degeneration and those with experimentally damaged visual cells. He concludes that the particular vulnerability of the visual cells to $\mathrm{X}$ rays, hyperbaric oxygen, high light intensity and iodoacetic acid may be due to the presence of a light-activated energy transfer system which is highly susceptible to detrimental oxidations. A note at the end of the symposium on the role of ubiquinone is particularly relevant to this thesis. A defect in protective mechanisms could be a crucial factor in the genetic disease. L. Cohen, in conjunction with Noell, uses similar findings as a springboard for speculation on the molecular mechanism of the initial events of vision. Not all the facts fit the theory (or vice versa) but it is a worth-while exercise with stimulating ideas and a framework for new thought. Finally, M. Keen and C. Chlouverakis present an interesting hypothesis on the mechanism of diabetic retinopathy which evoked considerable discussion and approval.

Poor proof-reading of one paper detracts from the otherwise very high standard of editing and presentation, and two contributors have submitted inferior photomicrographs. It would have helped the wide range of non-retinal biochemists whom the book will surely interest if a consistent labelling of retinal soctions had been adopted. Nevertheless the book begins to fill, most 